\title{
ФОРМУВАННЯ ПРАКТИЧНИХ НАВИЧОК СТУДЕНТІВ-ПЕДІАТРІВ У МЕДИЧНИХ ЗАКЛАДАХ ВИЩОЇ ОСВІТИ
}

\author{
V. A. Dihtiar, O. G. Sadovenko, M. O. Kaminska \\ Dnipro State Medical University
FORMATION OF PRACTICAL SKILLS PEDIATRIC STUDENTS IN MEDICAL INSTITUTIONS OF HIGHER EDUCATION

\begin{abstract}
Анотація. Лікар-спеціаліст, закінчуючи вищий навчальний заклад, повинен мати високу конкурентоспроможність. Науково-дослідна робота (НДР) студентів є однією з форм підвищення рівня освіти у вищих медичних навчальних закладах. НДР студентів - це основна складова частина професійної підготовки майбутнього лікаря, що передбачає навчання студентів методик та методології наукового дослідження. Самостійна робота студентів поділяється на навчально-дослідницьку, яка включається в навчальний процес з дисципліни і проводиться в робочий час, і науково-дослідницьку, яка виконується у позанавчальний час. Найефективніше НДР реалізується в студентських наукових гуртках. Форми організації роботи гуртківців - це дебати, практикум, індивідуальна робота в клініці тощо. Особлива увага приділяється відпрацюванню практичних навичок студентами в кімнаті практичних навичок на кафедрі. Під керівництвом викладача або інтернів, старшокурсників $є$ можливість студентів молодших курсів оволодіти виконанням основних практичних навичок, що не завжди доступно під час практичного заняття. Велику ефективність показала організація хірургічної школи на кафедрі, де одночасно мали можливість працювати інтерни, старшокурсники та студенти молодших курсів під керівництвом викладачів. Новою формою проведення студентського наукового гуртка є майстер-класи. За власним бажанням студенти виконують власні НДР під керівництвом викладача, результати яких доповідаються на секції «Хірургія» академії та інших конференціях, конгресах тощо. Багаторічний досвід кафедри свідчить про те, що студенти-гуртківці краще оволодівають теоретичними знаннями, практичними навичками та професійними вміннями, ніж ті, що не беруть участі у студентських наукових гуртках.
\end{abstract}

Ключові слова: лікар-спеціаліст; дитячий хірург; студентський науковий гурток.

Abstract. A specialist doctor graduating from a higher education institution must be highly competitive. Research work (RW) of students is one of the forms of raising the level of education in higher medical educational institutions. Student research is the main part of the professional training of the future doctor, which involves teaching students the methods and methodology of research. Independent work of students is divided into educational and research, which is included in the educational process of the discipline and is carried out during working hours, and research, which is performed in extracurricular activities. The most effective RW is implemented in student research society. Forms of organizing the work of group members are debates, workshops, individual work in the clinic, etc. Particular attention is paid to the development of practical skills by students in the room of practical skills at the department. Under the guidance of a teacher, or interns, undergraduates have the opportunity for junior students to master the implementation of basic practical skills, which is not always available during practical training. The organization of the surgical school at the department showed great efficiency, where at the same time interns, seniors and junior students had the opportunity to work under the guidance of teachers. A new form student scientific society is master classes. At their own request, students perform their RW under the guidance of the teacher, the results of which are reported at the section "Surgery" of the academy and other conferences, congresses, etc. The long-term experience of the department shows that students-students master theoretical knowledge, practical skills and professional skills better than those who do not participate in student scientific society.

Key words: specialist doctor; pediatric surgeon; student scientific society.

Вступ. Лікар-спеціаліст, закінчуючи вищий навчальний заклад, повинен мати високу конкуренто- спроможність. Науково-дослідна робота студентів (НДР) є однією з форм підвищення рівня освіти у

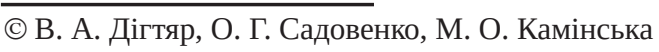


вищих медичних навчальних закладах. Це основна складова частина професійної підготовки майбутнього лікаря дитячого хірурга, ортопеда-травматолога.

Згідно з Постановою президії Академії наук України «Про розвиток науки та трансформацію суспільства: концепція для України», провідною метою наукової, науково-технічної та інноваційної політики системи вищої освіти залишається забезпечення підготовки спеціалістів на рівні міжнародних кваліфікаційних вимог.

Мета статті - провести аналіз роботи студентського наукового гуртка та його впливу на формування лікаря-спеціаліста, дитячого хірурга, ортопеда-травматолога за матеріалами кафедри дитячої хірургії, ортопедії та травматології ДДМУ.

Теоретична частина. Науково-дослідна робота студентів - це основна складова частина професійної підготовки майбутнього лікаря дитячого хірурга, ортопеда-травматолога, що передбачає навчання студентів методик та методології наукового дослідження, а також систематизацію науково-дослідницької діяльності. В Україні НДР студентів формується згідно з нормативно-законодавчими документами [2, 3].

Поняття НДР студентів включає два взаємопов'язаних елементи: наукові дослідження, які здійснюють студенти під керівництвом викладачів кафедри, навчання студентів елементів дослідницької діяльності, організації та методики наукової творчості [1, 3].

Самостійна робота студентів поділяється на навчально-дослідницьку, яка включається в навчальний процес із дисципліни і проводиться в робочий час, і науково-дослідницьку, яка виконується у позанавчальний час.

НДР студентів, яка виконується в позанавчальний час, складається $з$ таких розділів роботи, як:

- робота в студентських наукових гуртках (СНГ) при кафедрах, наукових товариствах, асоціаціях тощо;

- участь у науково-дослідницькій роботі кафедри;

- виступи на засіданнях СНГ із доповідями, повідомленнями, клінічними випадками;

- виступи на клінічних конференціях та науково-практичних конференціях, що проводяться у навчальному закладі;

- виступи з доповідями та повідомленнями на регіональних науково-практичних, міжвузівських конференціях студентів та молодих учених;

- участь у регіональних, міжвузівських олімпіадах, конкурсах на кращі наукові роботи.
Найефективніше НДР реалізується в студентських наукових гуртках (СНГ). Саме через студентський науковий гурток ми формуємо кадри майбутніх лікарів дитячих хірургів, які мають достатньо високі теоретичний та практичний рівні знань.

Студентський науковий гурток - студентська організація на кафедрі дитячої хірургії, ортопедії та травматології ДДМУ, учасниками якої є студенти університету різних курсів навчання, яка формується за напрямком наукової діяльності кафедри відповідно до затвердженої теми НДР [2].

Робота гуртка проводиться згідно з положенням про студентський науковий гурток. Його відвідують студенти I-VI курсів медичних факультетів та інтерни дитячі хірурги.

Основні напрямки роботи гуртка:

- загальні питання дитячої хірургії, ортопедії та травматології;

- медична реабілітація дітей з вадами розвитку, хірургічними, ортопедичними захворюваннями i наслідками травм;

- оволодіння практичними навичками та вміннями, необхідними в роботі дитячого хірурга, ортопеда-травматолога.

Мета роботи СНГ кафедри передбачає:

- виявлення талановитих та здібних студентів, схильних до науково-дослідницької роботи;

- участь студентів у дослідженнях за проблемою наукової діяльності кафедри;

- оволодіння навичками виконання наукової роботи під час навчання, а також після закінчення навчального закладу та під час подальшої практичної роботи.

Основними завданнями СНГ залишаються:

- залучення до роботи активних студентів, які виявляють інтерес до наукової та науково-дослідницької роботи;

- організація та керівництво науково-дослідницькою роботою студентів СНГ;

- поглиблене вивчення студентами дитячої хірургії, ортопедії та травматології;

- формування світогляду лікаря дитячого хірурга, ортопеда-травматолога та морально-етичного підходу до лікування дітей;

- виховання майбутнього лікаря дитячого хірурга, ортопеда-травматолога з високим рівнем професійної підготовки.

Таким чином, СНГ дозволяє обрати тих студентів, які мають здібності до наукової роботи та мотивацію для підвищення своєї лікарської майстерності, розвитку своєї організаторської спроможності. 
Робота у СНГ дає можливості студентам оволодіти різними методами свого вдосконалення. Протягом навчального року студенти беруть участь у клінічних обходах із досвідченими викладачами, працюють у відділеннях, беруть участь у чергуваннях.

СНГ дозволяє обрати тих студентів, які мають здібності до наукової роботи та мотивацію для підвищення своєї лікарської майстерності, розвитку своєї організаторської спроможності.

Загальне керівництво роботою СНГ проводить завідувач кафедри дитячої хірургії, ортопедії та травматології ДДМУ, а поточну роботу здійснюе науковий керівник СНГ, це завжди досвідчений викладач. У роботі СНГ активну участь беруть обов'язково всі викладачі кафедри, аспіранти, клінічні ординатори.

У СНГ кафедри дитячої хірургії, ортопедії та травматології ДДМУ беруть участь студенти різних курсів та факультетів. Засідання проводиться 1-2 рази на місяць за тематикою, затвердженою на кафедральному засіданні на початку навчального року. Річний план роботи СНГ включає зазначені теми, куратора засідання, форми роботи студентів та відділення, на базі якого будуть вони працювати. Вся ця інформація обов’язково доступна на сайті кафедри та доводиться до відома студентів куратором та старостою СНГ.

Форми організації роботи гуртківців - це дебати, практикум, індивідуальна робота в клініці тощо [1]. Матеріали до засідання СНГ розробляє куратор. На початку засідання куратор знайомить студентівгуртківців з обраною темою у вигляді міні-лекції, формулює мету та план засідання.

Другий етап передбачає залучення студентів-доповідачів, які отримали напередодні завдання та самостійно опрацювали найбільш вагомі новітні здобутки в діагностиці або лікуванні за темою у вигляді мультимедійних презентацій. Це роботи, присвячені актуальним питанням сучасної діагностики, лікування, реабілітації дітей з хірургічними захворюваннями та вадами розвитку. Студенти більш глибоко вивчають особливості діагностики і лікування, а також знайомляться з досягненнями та перспективами розвитку висококваліфікованої медичної допомоги дітям.

Велика увага приділяється питанням медичної, соціальної реабілітації дітей з вадами розвитку, наслідками захворювань та травм.

Заключний етап кожного засідання - це дискусія, під час якої гуртківці обговорюють сучасні аспекти діагностики та лікування хірургічних захворювань у дітей різного віку.
Особлива увага приділяється відпрацюванню практичних навичок студентами у кімнаті практичних навичок на кафедрі. Під керівництвом викладача або інтернів, старшокурсників $є$ можливість студентів молодших курсів оволодіти виконанням основних практичних навичок, що не завжди доступно під час практичного заняття.

Велику ефективність показала організація хірургічної школи на кафедрі, де одночасно мали можливість працювати інтерни, старшокурсники та студенти молодших курсів під керівництвом викладачів. Чергування також значно допомагають студентам в оволодінні практичними навичками, можливість прослідкувати особливості надання медичної допомоги на різних етапах (клінічне обстеження, спеціальні методи дослідження тощо), підвищують клінічне мислення й дають спробу стати активним учасником у розробці програми обстеження, лікування та реабілітації дитини з хірургічною, ортопедичною і травматологічною патологією.

Новою формою проведення СНГ є майстер-класи. На кафедрі вони проводяться за напрямками хірургічного лікування з використанням тренажерів. Викладачі, які організовують ці майстер-класи, проводять їх разом із лікарями-інтернами. Так, майстер-клас з ендоскопічного лікування хірургічної патології дітей проводився неодноразово у майстер-класі з використанням лапароскопічних установок. Це дало змогу самостійно відчути роботу хірурга.

Важливим аспектом становлення майбутнього лікаря є оволодіння толерантністю та взаємоповагою. Викладачі дотримуються педагогічної етики та моралі, особистим прикладом стверджують принципи загальнолюдської моралі.

На засіданні СНГ студентам прищеплюються деонтологічні принципи лікарської професії - належного співчутливого ставлення до хворої дитини та її родичів. Акцентується увага на тому, що доброзичливе ставлення до дитини та ії батьків, заспокійливе слово лікаря, обнадійлива обгрунтована інформація є могутніми засобами мобілізації захисних сил організму на його одужання.

Багаторічний досвід кафедри свідчить про те, що студенти-гуртківці краще оволодівають теоретичними знаннями, практичними навичками та професійними вміннями, ніж ті, що не беруть участі у студентських наукових гуртках.

За власним бажанням студенти виконують власні НДР під керівництвом викладача, результати яких доповідаються на секції хірургічних хвороб академії та інших конференціях, конгресах тощо. Стало 
традицією протягом останніх років брати участь у міжнародних конгресах студентів і молодих учених.

Карантин накладає великий відбиток на навчання студентів. Складно працювати студентам і у науковому гуртку кафедри. Немає можливості оволодіти практичними навичками у повному об’ємі, відсутнє спілкування з дітьми, навіть складно між собою спілкуватися, але робота проводиться і гурток працює! Проводяться он-лайн засідання та індивідуальна робота зі студентами викладачами кафедри. Засідання присвячуються одній актуальній темі дитячої хірургії, ортопедії або травматології з використанням сучасних платформ для онлайн спілкування.

Складніше з оволодінням практичними навичками, якими повинні додатково оволодіти студенти. Виконання навичок представлені у відеофільмах, знятих під час виконання безпосередньо у відділеннях або у класі на муляжах. Вони транслюються он-лайн, і викладач коментує особливості проведення маніпуляції. Студент має можливість теоретично ознайомитися з виконанням навички, а також спілкуватися та ставити питання під час транслювання.

Результатом роботи наших гуртківців $є$ участь у роботі наукових студентських конференцій. Так, цього року були направлені наші роботи до участі у Міжнародному медико-фармацевтичному конгресі студентів і молодих учених, який проходив 6-9 квітня 2021 р. на базі Буковинського державного медичного університету. Цьогоріч конгрес відбувався у режимі он-лайн за участі студентів та молодих учених з 51 країни світу! Такий формат міжнародного конгресу надав можливість обмінятися молодим ученим досвідом, поділитися своїми досягненнями, науковими задумами та ідеями, подарував натхнення до пошуку нових звершень у медичній науці! Наші студенти взяли активну участь у роботі конгресу, а один - отримав диплом II ступеня.

Також всі гуртківці взяли активну участь у роботі XXI наукової конференції студентів та молодих учених «Новини і перспективи медичної науки»

\section{Список літератури}

1. Аналіз ставлення студентів вищого медичного навчального закладу до самостійної роботи як виду навчальної діяльності / Н. І. Рублевська, О. А. Шевченко, Г. С. Канюка [та ін.] // Медична освіта. - 2017. - № 2. С. 64-67.

2. Про вищу освіту : Закон України від 01.07.2014 р. № 1556-VII [Електронний ресурс]. - Режим доступу : http://zakon.rada.gov.ua/laws/show/ 1556-18. нашого університету, яка цього року також проводилася он-лайн. Були представлені мультимедійні доповіді за результатами роботи в цьому навчальному році.

За останні 5 років з 56 осіб, які відвідували студентський науковий гурток протягом навчання, надійшло в інтернатуру 28 осіб. Інтерни дитячі хірурги, які відвідували СНГ, набагато успішніше проходили навчання в інтернатурі, ніж ті, хто не працював у науковому студентському гуртку.

Після успішного навчання в інтернатурі за спеціальністю «Дитяча хірургія» в клінічну ординатуру були зараховані 7 студентів, з них 5 випускників факультету іноземних студентів. До навчання в аспірантурі за спеціальністю «Дитяча хірургія» було направлено 1 студента, який отримав високий рівень теоретичної та практичної підготовки під час навчання у ДДМУ та проходження інтернатури за фахом «Дитяча хірургія».

Висновки та перспективи подальших досліджень. 1. СНГ допомагає розвинути творче та аналітичне мислення студента, виробити вміння застосовувати теоретичні знання і сучасні методи діагностики та лікування в практичній діяльності.

2. Робота в СНГ дає можливість студентам краще освоїти дитячу хірургію, опанувати практичні навички і вміння, необхідні для подальшої роботи лікаря дитячого-хірурга.

3. Студенти СНГ можуть поглиблювати свої теоретичні знання з обраної ними складної спеціальності дитячого хірурга.

4. Робота в СНГ дає можливість почати науковий пошук і потім займатися власними дослідженнями протягом навчання та в подальшій практичній діяльності лікаря дитячого-хірурга.

5. Планується подальше вдосконалення дистанційних форм роботи зі студентами СНГ, які беруть участь у науково-дослідницькій роботі кафедри.

6. Планується проведення анкетування студентіввипускників, які відвідували науковий гурток і брали участь у науково-дослідницькій роботі кафедри протягом навчання, та аналіз отриманих результатів для подальшого вдосконалення роботи СНГ.

3. Про національну програму інформатизації : Закон України [зі змінами, внесеними Законом України від 13.04.2020 p. № 554-IX] [Електронний ресурс]. - Режим доступу : http://zakon5.rada.gov.ua/laws/show/74/98\%D0\%B2\%D1\%80. 


\section{References}

1. Rublevska, N.I., Shevchenko, O.A., Kaniuka, H.S., Kramarova, Yu.S., Shchudro, S.A., Zaitsev, V.V., ... Dziak, M.V. (2017). Analiz stavlennia studentiv vyshchoho medychnoho navchalnoho zakladu do samostiinoi roboty yak vydu navchalnoi diialnosti [Analysis of the attitude of students of higher medical education to independent work as a type of educational activity]. Medychna osvita - Medical Education, 2, 64-67 [in Ukrainian].

2. Zakon Ukrainy Pro vyshchu osvitu vid 01.07.2014 r. № 1556-VII [Law of Ukraine On Higher Education dated
01.07.2014 No. 1556-VII]. Retrieved from: http://zakon. rada.gov.ua/laws/show/1556-18 [in Ukrainian].

3. Zakon Ukrainy Pro natsionalnu prohramu informatyzatsii vid 13.04.2020 r. № 554-IX [Law of Ukraine On the National Informatization Program dated 13.04.2020 No. 554-IX]. Retrieved from: https://zakon.rada.gov.ua/ laws/show/74/98-вp\#Text [in Ukrainian]. 